\title{
An Interaction between Magnesium and Calcium in Cabbage-Nutrition
}

\author{
Tetsuo Hara, Tagayasu Tanaka*, Yoji Sonoda, and Iwao IwaI \\ Faculty of Agriculture, Gifu University, Gifu
}

\begin{abstract}
Summary
Cabbage plants were water-cultured under a combination of 4 levels of magnesium $(0,5,25,125 \mathrm{ppm})$ and calcium $(4,20,100,500 \mathrm{ppm})$, and the effect of the elements supplied on the growth and nutrient status of the plants was studied.

The dry weight of a whole plant (plant-top+roots) and inner leaves increased with increasing levels of $\mathrm{Mg}$ from 0 to $125 \mathrm{ppm}$ when the concentration of $\mathrm{Ca}$ in the culture solution was high, whereas it decreased at higher levels of $\mathrm{Mg}$ when the concentration of $\mathrm{Ca}$ was low. The contents of $\mathrm{Mg}$ and $\mathrm{Ca}$ in the plants increased with increasing levels of each element, and an increase in the content of one element caused a decrease in the content of the other element. The plants high in $\mathrm{Mg}$ or $\mathrm{Ca}$ were liable to suffer from deficiency injury involving $\mathrm{Ca}$ or $\mathrm{Mg}$. The critical contents of $\mathrm{Mg}$ and $\mathrm{Ca}$ in outer leaves resulting in deficiency injury were about 0.1 and $1.3 \%$ on a dry matter basis, respectively.

A suitable range of the $\mathrm{Ca} / \mathrm{Mg}$ content ratio as well as adequate contents of $\mathrm{Mg}$ and $\mathrm{Ca}$ in each organ is considered to be favorable for the growth of cabbage plants.
\end{abstract}

\section{Introduction}

Magnesium and calcium are recognized to be essential for the growth of higher plants. The critical contents of the elements in plants leading to deficiency injury have been evaluated in many crops, and their roles in plant-tissues are being clarified through many studies. The excess injury by magnesium in crops, on the other hand, has also been studied(2). Magnesium is not called an alkaline earth metal but calcium. They are divalent cations. There is abundant evidence that divalent cations compete with each other in the uptake by higher plants, and the competition between magnesium and calcium is generally considered as an antagonistic interaction.

To reconfirm the information, the present experiment was aimed at studying the combined effect of graded levels of both magnesium and calcium in a culture solution on the growth and nutrient status of cabbage plants. In connection with this, the results of the

Received for publication June 14, 1976

* Present address : Collective Office of Gifu Prefecture, Tsukasa-cho, Gifu intracellular distribution of magnesium and calcium in the cabbage leaves have already been presented in the preceding report (1).

\section{Materials and Methods}

On April 14, 1973, seeds of a Nagaoka cabbage variety, Soshu, were sown in vermiculite with tap-water and grown in a green house. On May 3, the seedlings were transferred into 4 liter-pots, with three seedlings per pot, containing a standard culture solution prepared with demineralized water and Wako Co. chemicals (1). The composition of the culture solution, in $\mathrm{mg} / \mathrm{l}$, was : $50 \mathrm{~N}, 20 \mathrm{P}, 50$ $\mathrm{K}, 100 \mathrm{Ca}, 50 \mathrm{Mg}, 2 \mathrm{Fe}, 1 \mathrm{~B}, 0.5 \mathrm{Mn}, 0.2 \mathrm{Zn}$, $0.05 \mathrm{Cu}$, and $0.05 \mathrm{Mo}$. Their chemical forms were $\mathrm{NaNO}_{3}, \mathrm{Na}_{2} \mathrm{HPO}_{4}, \mathrm{~K}_{2} \mathrm{SO}_{4}, \mathrm{CaCl}_{2}, \mathrm{MgSo}_{4}$, $\mathrm{FeSO}_{4}, \mathrm{H}_{3} \mathrm{BO}_{3}, \mathrm{MnSO}_{4}, \mathrm{ZnSO}_{4}, \mathrm{CuSO}_{4}$, and $\mathrm{Na}_{2} \mathrm{MoO}_{4}$, respectively. The culture solution was aerated at one hour intervals and renewed once a week, and its $\mathrm{pH}$ was adjusted to be 5 with $1 \mathrm{~N}-\mathrm{H}_{2} \mathrm{SO}_{4}$ or $1 \mathrm{~N}-\mathrm{NaOH}$. Two seedlings per pot had been thinned until May 20 . On May 27, the plants were imposed upon 16 treatments combined with 4 levels of magnesium $(0,5,25,125 \mathrm{ppm})$ and calcium $(4,20,100$, 
$500 \mathrm{ppm}$ ), which were added as $\mathrm{MgSO}_{4}$ and $\mathrm{CaCl}_{2}$ to the culture solution in two replications.

At harvest, August 2, the plants were separated into inner leaves (which were composed of a cabbage-head), outer leaves(which were not part of the cabbage-head), stems (which were deprived of all the leaves), and roots. After the roots were washed with demineralized water, all the organs were dried at $70^{\circ} \mathrm{C}$ for 3 days, weighed, and milled for chemical analysis. But the plants at $125 \mathrm{ppm}$ $\mathrm{Mg}$ and $4 \mathrm{ppm} \mathrm{Ca}$ were sampled on June 28 when they were almost dead.

After digestion of the plant-samples with the sulfuric-nitric-perchloric acid mixture, magnesium and calcium were determined by the atomic absorption method with a Hitachi Model 208 spectrophotometer.

\section{Results and Discussion}

The dry weight of a whole plant (planttop+roots) and inner leaves increased with increasing levels of magnesium from 0 to 125 $\mathrm{ppm}$ when the concentration of calcium in the culture solution was high, whereas it decreased at high levels of magnesium when the concentration of calcium was low (Table 1). Symptoms of the deficiency injury by

Table 1 Dry weight of a whole plant and inner leaves, and the inner leaves/whole plant ratio

\begin{tabular}{|c|c|c|c|c|c|}
\hline \multicolumn{2}{|c|}{ Treatments } & \multirow{2}{*}{$\begin{array}{l}\text { Plot } \\
\text { No. }\end{array}$} & \multirow{2}{*}{$\begin{array}{c}\text { Whole plant } \\
\text { (g/plant) } \\
\text { a }\end{array}$} & \multirow{2}{*}{$\begin{array}{c}\text { Inner leaves } \\
\text { (g/plant }) \\
\mathrm{b}\end{array}$} & \multirow{2}{*}{$\mathrm{b} / \mathrm{a}$} \\
\hline $\mathrm{Mg}$ & $\mathrm{Ca}$ & & & & \\
\hline \multicolumn{2}{|c|}{$(\mathrm{ppm})$} & & & & \\
\hline 0 & 4 & 1 & 18.2 & 2.2 & 0.12 \\
\hline 0 & 20 & 2 & 28.5 & 7.4 & 0.26 \\
\hline 0 & 100 & 3 & 56.3 & 20.3 & 0.36 \\
\hline 0 & 500 & 4 & 54.4 & 19. 0 & 0.35 \\
\hline 5 & 4 & 5 & 26.2 & 9.2 & 0.35 \\
\hline 5 & 20 & 6 & 37.1 & 12.2 & 0.33 \\
\hline 5 & 100 & 7 & 79.1 & 38.0 & 0.48 \\
\hline 5 & 500 & 8 & 67.6 & 29.1 & 0.43 \\
\hline 25 & 4 & 9 & 19.0 & 6.8 & 0.36 \\
\hline 25 & 20 & 10 & 50.3 & 21.1 & 0.42 \\
\hline 25 & 100 & 11 & 74.6 & 34.9 & 0.47 \\
\hline 25 & 500 & 12 & 78.0 & 37.4 & 0.48 \\
\hline 125 & 4 & 13 & 1.5 & 0.0 & - \\
\hline 125 & 20 & 14 & 32.0 & 9.6 & 0.30 \\
\hline 125 & 100 & 15 & 62.9 & 28.3 & 0.45 \\
\hline 125 & 500 & 16 & 81.9 & 26.0 & 0.44 \\
\hline
\end{tabular}

magnesium were observed in all the plots at $0 \mathrm{ppm} \mathrm{Mg}$ except the plot at $0 \mathrm{ppm} \mathrm{Mg}$ and $4 \mathrm{ppm} \mathrm{Ca}:$ Yellow-brown speckles appeared along the edges of the outer leaves which looked chlorotic in spots. The severe deficiency injury by calcium occurred in all the plots at $4 \mathrm{ppm} \mathrm{Ca}$ and slight injury in all the plots at $20 \mathrm{ppm} \mathrm{Ca}$ except the plot at $25 \mathrm{ppm} \mathrm{Mg}$ and $20 \mathrm{ppm} \mathrm{Ca}$, and the symptoms were characterized by the abnormal expansion of the young leaves with breakages at their marginal parts and by the subsequent development of necrosis between leaf-veins of the deformed leaves which felt very stiff.

The inner leaves/whole plant ratio decreased when the plants were deficient in magnesium or calcium (Table 1). This decrease brings about a loss in commercial values of cabbage plants, because the inner leaves are the main part to be eaten among cabbage-organs.

Tables 2 and 3 show the results of the contents of magnesium and calcium in the plants. As the concentration of magnesium in the culture solution increased, the content of magnesium in each organ increased and the content of calcium decreased. As the concentration of calcium increased, the content of magnesium decreased and the content of calsium increased. That is, such tendencies were

Table 2 Content of magnesium in several organs (\% on a dry matter basis)

\begin{tabular}{|c|c|c|c|c|c|}
\hline \multicolumn{2}{|c|}{ Treatments } & \multicolumn{4}{|c|}{ Organs } \\
\hline $\mathrm{Mg}$ & $\mathrm{Ca}$ & Inner leaves & Outer leaves & Stem & Roots \\
\hline \multicolumn{2}{|c|}{$(\mathrm{ppm})$} & 0.16 & 0.10 & 0.19 & 0.41 \\
\hline 0 & 20 & 0.12 & 0.07 & 0.17 & 0.23 \\
\hline 0 & 100 & 0.07 & 0.06 & 0.10 & 0.20 \\
\hline 0 & 500 & 0.05 & 0.05 & 0.14 & 0.15 \\
\hline 5 & 4 & 0.30 & 0.40 & 0.52 & 0.41 \\
\hline 5 & 20 & 0.19 & 0.29 & 0.47 & 0.33 \\
\hline 5 & 100 & 0.12 & 0.15 & 0.24 & 0.26 \\
\hline 5 & 500 & 0.11 & 0.13 & 0.20 & 0.15 \\
\hline 25 & 4 & 0.42 & 1.78 & 0.80 & 0.63 \\
\hline 25 & 20 & 0.32 & 1.25 & 0.67 & 0.62 \\
\hline 25 & 100 & 0.16 & 0.49 & 0.37 & 0.37 \\
\hline 25 & 500 & 0.12 & 0.22 & 0.23 & 0.36 \\
\hline 125 & 4 & - & 2. 20 & 1. 28 & 0.92 \\
\hline 125 & 20 & 0.57 & 2.05 & 1.08 & 0.88 \\
\hline 125 & 100 & 0.23 & 1.01 & 0.65 & 0.44 \\
\hline 125 & 560 & 0.15 & 0.40 & 0.37 & 0.44 \\
\hline
\end{tabular}


Table 3 Content of calcium in several organs ( $\%$ on a dry matter basis)

\begin{tabular}{|c|c|c|c|c|c|}
\hline \multicolumn{2}{|c|}{ Treatments } & \multicolumn{4}{|c|}{ Organs } \\
\hline $\mathrm{Mg}$ & $\mathrm{Ca}$ & Inner leaves & Outer leaves & Stem & Roots \\
\hline \multicolumn{2}{|c|}{$(\mathrm{ppm})$} & 0.39 & 1.04 & 0.39 & 0.44 \\
\hline 0 & 20 & 0.51 & 1. 38 & 0.56 & 0.53 \\
\hline 0 & 100 & 0.57 & 2.15 & 0.61 & 0.70 \\
\hline 0 & 500 & 0.70 & 2. 20 & 0.63 & 0.74 \\
\hline 5 & 4 & 0.40 & 1.04 & 0.34 & 0.44 \\
\hline 5 & 20 & 0.49 & 1. 42 & 0.48 & 0.50 \\
\hline 5 & 100 & 0.57 & 2.50 & 0.62 & 0.68 \\
\hline 5 & 500 & 0.61 & 2.81 & 0.64 & 0.73 \\
\hline 25 & 4 & 0.34 & 0.65 & 0.31 & 0.38 \\
\hline 25 & 20 & 0.45 & 1.43 & 0.42 & 0.45 \\
\hline 25 & 100 & 0.50 & 2. 49 & 0.55 & 0.64 \\
\hline 25 & 500 & 0.54 & 2. 62 & 0.56 & 0.66 \\
\hline 125 & 4 & - & 0.40 & 0.28 & 0.30 \\
\hline 125 & 20 & 0.23 & 1.00 & 0.37 & 0.32 \\
\hline 125 & 100 & 0.40 & 1.55 & 0.41 & 0.53 \\
\hline 125 & 500 & 0.47 & 2. 46 & 0.53 & 0.52 \\
\hline
\end{tabular}

found as an increase in the content of magnesium being accompanied with a decrease in the content of calcium, and vise versa

As there was an antagonistic interaction between the magnesium and calcium uptake by cabbage plants, the ratio of the content of calcium to that of magnesium in the plants $(\mathrm{Ca} / \mathrm{Mg}$ ratio) was taken into consideration in drawing a figure of relationship between the relative values of the dry weight of a whole plant and the contents of magnesium and calcium in outer leaves. The relative values were computed as the percentage of the dry weight of each plot to that of the plot at 125 $\mathrm{ppm} \mathrm{Mg}$ and $500 \mathrm{ppm} \mathrm{Ca}$ in which the plants had the highest dry weight. As long as the plots having a $\mathrm{Ca} / \mathrm{Mg}$ ratio below 5 in the case of the dry weight- $\mathrm{Mg}$ content relationship and above 20 in the dry weight-Ca content relationship are excluded, correlation lines can be drawn as in Fig.1. This figure indicates that the critical contents of magnesium and calcium in outer leaves which cause a decrease in the dry weight due to deficiency injury are about 0.1 and $1.3 \%$ on a dry matter basis, respectively. Cabbage plants are reported to have the highest requirement for calcium among many crops (4), and from this result, are considered to require more calcium than

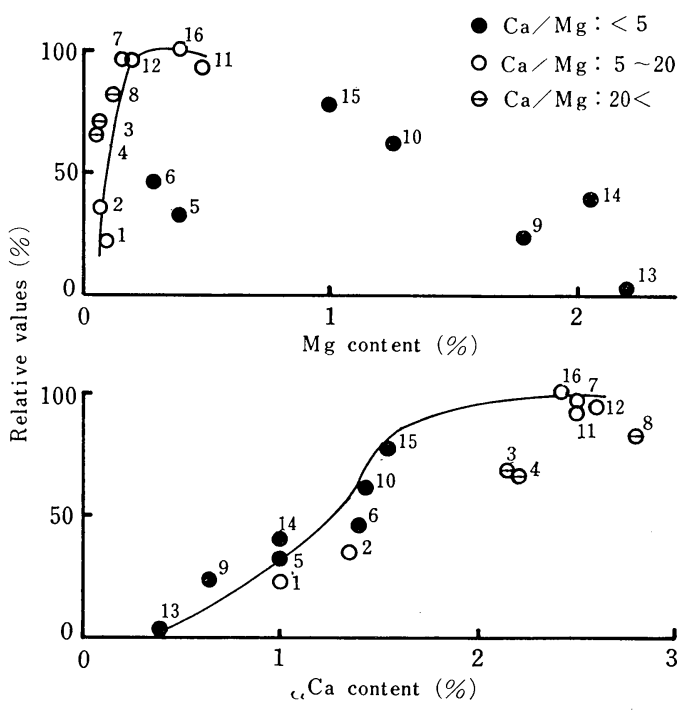

Fig. 1 Relationship between the relative values of the dry weight of a whole plant and the contents of magnesium and calcium in outer leaves. The numbers in the figure indicate the same plot No. as shown in Table 1

magnesium. It is apparent that the plants at $0 \mathrm{ppm} \mathrm{Mg}$ and $100 \mathrm{ppm} \mathrm{Ca}, 0 \mathrm{ppm} \mathrm{Mg}$ and $500 \mathrm{ppm} \mathrm{Ca}$, and $5 \mathrm{ppm} \mathrm{Mg}$ and $500 \mathrm{ppm} \mathrm{Ca}$ were suffering from the deficiency injury by magnesium, and that the plants at $25 \mathrm{ppm} \mathrm{Mg}$ and $4 \mathrm{ppm} \mathrm{Ca}, 125 \mathrm{ppm} \mathrm{Mg}$ and $4 \mathrm{ppm} \mathrm{Ca}$, and $125 \mathrm{ppm} \mathrm{Mg}$ and $20 \mathrm{ppm} \mathrm{Ca}$ were suffering from the deficiency injury by calcium. It is worthy of note, however, that the plants in these plots seem to have suffered not only from the deficiency injury by each element but also from a kind of excess injury by calcium or magnesium. This is understandable from the fact that the $\mathrm{Ca} / \mathrm{Mg}$ ratio of these plants was very high or low. Therefore, a suitable range of the $\mathrm{Ca} / \mathrm{Mg}$ ratio as well as adequate contents of magnesium and calcium in each organ favors the growth of cabbage plants, and an extraodinary range beyond the range triggers the imbalance in mineral nutrition in the plants which is detrimental to the normal growth. In connection to this, Tanaka et al. (3) have reported that the $\mathrm{Ca} / \mathrm{Mg}$ ratio in corn leaves beyond a certain range caused the reduced growth of the plants, accompanied with a decrease in the photosynthetic rate of their leaves. 


\section{Literature Cited}

1. HARA, T., T. TANAKA, Y.SONODA, and I. IWAI. 1977. Intracellular distribution of calcium and magnesium in mature cabbage leaves as affected by their nutrient status. J. Japan. Soc. Hort. Sci. $46: 26--31$

2. Shimada, N. 1972. Studies on the excess injury of magnesium in the crops. The Transactions of the Faculty of Horticulture, Chiba Univ. 6:1-105. (Japanese with English summary)

3. TANAKA, A., and T.HARA. 1972. Nutrio- physiological studies on the photosynthetic rate of the leaf (Part 4). Effect of calcium and magnesium status on the photosynthetic rate in the corn plant. J. Sci. Soil Manure, Japan $43: 218-222$. (Japanese with English summary)

4. TANAKA, A., T. TADANO, and M. YAMADA. 1973. Studies on the comparative plant nutrition (Part 1). Comparison of adaptability to bases among crop plants (I). Adaptability to calcium. J.Sci. Soil Manure, Japan $44: 334$ -339. (Japanese with English summary)

$$
\begin{aligned}
& \text { キャベツ筷養におけるマグネシウムとカルシウムの相互作用について }
\end{aligned}
$$

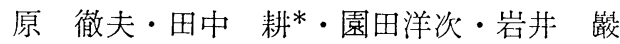

$$
\begin{aligned}
& \text { （岐泉大学農学部 * 現 岐皁県総合庁舍内岐皁県企画部） }
\end{aligned}
$$

\section{摘要}

キャベッ（長岡交配早秋）を 4 段階の $\mathrm{Mg}$ 濃度 $(0,5$, $25,125 \mathrm{ppm})$ と $\mathrm{Ca}$ 濃度 $(4,20,100,500 \mathrm{ppm})$ の組 合わせによる 16 種類の水耕液で栽培し，これら要素供 給量がキャベッの生青におよぼす影響を調查した。

全乾物重就よび球葉の乾物重は水耕液中の $\mathrm{Mg}$ 濃度の 増加により, 水耕液中の $\mathrm{Ca}$ 濃度が高い場合は直線的に 上昇し，低い場合には上型した後高濃度で低下した，植 物体の $\mathrm{Mg}$ あるいは $\mathrm{Ca}$ 含有率は水耕液中のそれぞれ の要素濃度の増加により上昇し, 他方の要素濃度の堌加
により低下した． $\mathrm{Mg}, \mathrm{Ca}$ 含有率が高い植物はそれぞれ $\mathrm{Ca}, \mathrm{Mg}$ 欠乏障害に陥りやすく，また全乾物重が低下す るときの限界 $\mathrm{Mg}, \mathrm{Ca}$ 含有率は外葉でそれぞれ $0.1,1.3$ \%(乾物当り) であった.

これらのことより，キャベッの良好な生育のために は, $\mathrm{Mg}$ および $\mathrm{Ca}$ 含有率が適当であるばかりでなく， $\mathrm{Ca} / \mathrm{Mg}$ 含有率比も適当な範囲にあることが望ましいと 考えられる. 